\title{
ESTIMASI JUMLAH KAPAL PENANGKAP IKAN OPTIMAL DI WPP 712 BERDASARKAN POTENSI SUMBER DAYA IKAN
}

\author{
Estimation of the Number of Fishing Vessel in WPP 712 Based on Fish Resources Potential \\ Oleh: \\ Wienda Justitia Ardiyani ${ }^{*}$, Budhi Hascaryo Iskandar ${ }^{2}$, Sugeng Hari Wisudo² \\ ${ }^{1}$ Program Studi Teknologi Perikanan Laut \\ 2 Departemen Pemanfaatan Sumberdaya Perikanan FPIK IPB \\ *Korespondensi: wiendajustitia@gmail.com
}

\begin{abstract}
ABSTRAK
Kondisi sumber daya ikan di WPP 712 saat ini berada dalam kondisi kurang baik. Hal tersebut didukung oleh Keputusan Menteri Kelautan dan Perikanan yang menyatakan bahwa potensi perikanan di WPP 712 saat ini memiliki nilai pemanfaatan yang melebihi angka yang artinya upaya penangkapan di WPP 712 sudah mencapai kategori fully-exploited. Oleh karena itu, perlu dilakukan pengurangan dalam upaya penangkapan ikan di WPP 712. Salah satu penyebab terjadinya upaya penangkapan berlebih karena tekanan penangkapan yang terjadi di WPP 712 didominasi oleh kegiatan perikanan tangkap skala kecil. Untuk dapat mengatasi tingginya upaya penangkapan yang dilakukan pertamatama perlu dilakukan analisis terhadap sebaran unit penangkapan yang ada. Oleh karena itu, penelitian ini bertujuan untuk mengetahui distribusi sebaran kapal penangkap ikan di WPP 712 dan menentukan estimasi jumlah kapal penangkap ikan optimal di WPP 712 berdasarkan potensi sumber daya ikan. Metode yang digunakan adalah metode analisis deskriptif dengan melakukan pengolahan data sekunder yang telah diperoleh dari Kementerian Kelautan Perikanan. Hasil yang telah diperoleh bahwa dalam delapan tahun terakhir jumlah kapal penangkap ikan yang beroperasi di WPP 712 mengalami perubahan secara fluktuatif. Total jumlah kapal tertinggi terdapat pada tahun 2014 yaitu dengan jumlah 98.828 unit kapal penangkap ikan dari berbagai ukuran. Hingga saat ini kategori kapal yang digunakan adalah dengan mengelompokkan kapal berdasarkan nilai GT kapal. Jumlah kapal penangkap ikan optimal berdasarkan nilai potensi sumber daya ikan saat ini untuk zona tangkap daerah sebesar 30.723 unit kapal dengan ukuran <5 GT hingga 21-30 GT dan 13.521 unit kapal berukuran 31-50 GT hingga kapal >200 GT.
\end{abstract}

Kata kunci: kapal penangkap ikan, potensial, WPP 712, zona tangkap

\section{ABSTRACT}

The fish resources in WPP 712 is currently in poor condition as stated in the Decree of the Minister of Marine Affairs and Fisheries, which states that the potential of fisheries in WPP 712 currently has exceeded maximum allowed utilization rate. This means that the fishing effort in WPP 712 has reached fully-exploited category. Therefore, it is necessary to reduce fishing efforts in WPP 712. One of the causes of overfishing is that fishing pressures that occur in WPP 712 dominated by small-scale fisheries. In order to overcome the high rate of fishing efforts, it is first necessary to analyze the distribution of existing fishing vessels units. This study aims to determine the distribution of fishing vessels in WPP 712 and determine the estimation number of optimal fishing vessels in WPP 712 based on fish resources potential. The method used in this research was descriptive analysis method. The data were obtained from the Ministry of Marine Affairs and Fisheries. The results show that in the last eight years the number of fishing vessels operating in WPP 712 has been fluctuating changes. The highest total number of fishing vessels was in 2014, with 98.828 fishing vessels of various sizes. Until now the fishing vessels category used is by grouping vessels based on the GT value of the ship. The number of 
optimal fishing vessels is based on the value of the current potential of fish resources for the regional catch zone was 30.723 vessels with a size of $<5$ GT up to 21-30 GT and 11.666 units of fishing vessels with a size of 31-50 GT to $>200$ GT.

Keywords: catch zone, fishing vessel, potentials, WPP 712

\section{PENDAHULUAN}

Kementerian Kelautan dan Perikanan (KKP) melalui analisis yang dilakukan sebagai indikator EAFM terhadap semua parameter sumber daya ikan, menghasilkan penilaian kondisi ekosistem WPP 712 pada masing-masing indikator yaitu habitat 112.50 (buruk), sumber daya ikan 133.33 (kurang baik), teknis penangkapan ikan 150.00 (kurang baik), sosial ekonomi 185.71 (sedang) dan kelembagaan 166.67 (sedang) (KKP, 2011). Menurut Keputusan Menteri Kelautan Dan Perikanan Republik Indonesia Nomor 50 tahun 2017 tentang estimasi potensi, jumlah tangkapan yang diperbolehkan, dan tingkat pemanfaatan sumber daya ikan di wilayah pengelolaan perikanan Negara Republik Indonesia menunjukkan bahwa potensi perikanan di WPP 712 sebesar 1.341 .631 ton dengan nilai pemanfaatan beberapa kategori sumber daya ikan telah melebihi angka 1 yang berarti termasuk dalam kategori fullyexploited, hal tersebut menunjukkan bahwa kegiatan penangkapan di WPP 712 sudah mencapai overfishing sehingga kegiatan penangkapan harus dikurangi.

Wilayah Pengelolaan Perikanan (WPP) 712 yang terletak di wilayah utara Pulau Jawa terdiri dari 8 provinsi dan memiliki 164 pelabuhan perikanan. Menurut Triarso (2012) potensi perikanan tangkap di Pantai Utara Jawa Tengah terindikasi telah mengalami tangkap lebih (overfishing) yang salah satunya disebabkan oleh tekanan penangkapan yang didominasi oleh perikanan tangkap skala kecil yang banyak beroperasi di perairan pantai. Berdasarkan data mengenai jumlah kapal perikanan yang diperoleh dari website data statistik resmi milik Kementerian Kelautan dan Perikanan Indonesia menyatakan bahwa total kapal perikanan di Provinsi Jawa Barat, Jawa Tengah, Jawa Timur, Kalimantan Selatan, Kalimantan Tengah, dan Provinsi Lampung mencapai 174.362 buah kapal, yang terdiri dari kapal jukung, kapal motor tempel, kapal motor berukuran <5 GT hingga kapal berukuran 100-200 GT (KKP 2012).

Perikanan yang tidak terkendali dapat terjadi pada pola perikanan open access. Perairan di Indonesia saat ini cenderung merupakan perairan open access yang apabila upaya penangkapan terus dilanjutkan maka hasil tangkapan dalam jangka panjang akan menurun. Salah satu cara yang dapat dilakukan dalam mengendalikan upaya penangkapan berlebih adalah dengan melakukan pengendalian terhadap upaya penangkapan. Upaya penangkapan berlebih dapat terjadi saat upaya penangkapan ikan yang dilakukan melebihi kapasitas yang seharusnya. Dalam hal ini salah satu yang termasuk upaya penangkapan adalah kapal penangkap ikan. Berdasarkan informasi mengenai potensi perikanan dan status perikanan yang ada di WPP 712 maka penelitian ini bertujuan untuk mengetahui distribusi sebaran kapal penangkap ikan di WPP 712 dan menentukan jumlah kapal penangkap ikan optimal di WPP 712 berdasarkan potensi sumber daya ikan. Informasi mengenai distribusi kapal penangkap ikan ini diharapkan dapat membantu penelitian selanjutnya mengenai optimalisasi kapal dan alat penangkapan ikan di WPP 712 sebagai upaya pengendalian kegiatan operasi penangkapan ikan di WPP 712.

\section{METODE PENELITIAN}

Pengumpulan dan pengolahan data dilakukan selama bulan September 2018 hingga Januari 2019 di Institut Pertanian Bogor. Penelitian yang dilakukan merupakan telaah terhadap data mengenai jumlah kapal penangkap ikan di WPP 712 selama delapan tahun terakhir (2009-2016). Data diperoleh dari Kementerian Kelautan Perikanan. Jenis data yang digunakan merupakan data jumlah kapal penangkap ikan di WPP 712. Data-data yang telah diperoleh akan disajikan dalam tabulasi dan diolah 
berdasarkan perhitungan dari masing-masing kebutuhan data. Pengolahan data dengan menggunakan microsoft excel dilakukan terhadap jumlah kapal penangkap ikan dan pembagian wilayah perairan. Penentuan luas perairan dilakukan berdasarkan Undang-undang No. 23 tahun 2014 tentang pemerintahan daerah dan mengacu pada titik-titik batas wilayah perairan berdasarkan Peraturan Menteri Kelautan dan Perikanan No. 18 tahun 2014 tentang wilayah pengelolaan perikanan Negara Republik Indonesia.

Pengolahan dan analisis data dilakukan dengan pertama-tama melaukan pembagian bobot persentase antara zona tangkap daerah dan pusat dilakukan berdasarkan luas perairan dan volume palka masing-masing ukuran kapal yang beroperasi di WPP 712. Pembagian dasar bobot persentase disampaikan pada Tabel 1.

Tabel 1 Pembagian bobot persentase antar zona tangkap

\begin{tabular}{ccc}
\hline Zona Tangkap & Luas perairan (100\%) & $\begin{array}{c}\text { Volume palka berdasarkan } \\
\text { ukuran }(100 \%)\end{array}$ \\
\hline Daerah & Provinsi (12 mil dari garis & $<5 \mathrm{GT}$ \\
& pantai) & $5-10 \mathrm{GT}$ \\
& $11-20 \mathrm{GT}$ \\
& & $21-30 \mathrm{GT}$ \\
\hline Pusat & $>12$ mil hingga 200 mil & $31-50 \mathrm{GT}$ \\
& & $51-100 \mathrm{GT}$ \\
& $101-200 \mathrm{GT}$ \\
& $>200 \mathrm{GT}$ \\
\hline
\end{tabular}

Total perbandingan antara zona tangkap daerah dan pusat sebagai berikut:

$\overline{\mathrm{Zd}}=\frac{\left(\frac{\mathrm{Ld}}{\mathrm{L}}\right)+\left(\frac{\mathrm{Vd}}{\mathrm{V}}\right)}{2}$

$\overline{\mathrm{Zd}} \quad$ : rasio rata-rata zona tangkap daerah

Ld : luas perairan $\left(\mathrm{m}^{2}\right)$

L $\quad$ : luas perairan total WPP $712\left(\mathrm{~m}^{2}\right)$

Vd : volume palka berdasarkan ukuran kapal $\left(\mathrm{m}^{3}\right)$

$\mathrm{V} \quad$ : volume palka dari total jumlah kapal di WPP $712\left(\mathrm{~m}^{3}\right)$

Bobot persentase antara zona tangkap daerah dan zona pusat tersebut digunakan untuk menentukan jumlah tangkapan yang diperbolehkan pada masing-masing zonasi. Pengolahan data lebih lanjut dilakukan untuk menentukan jumlah kapal berdasarkan masing-masing ukuran kapal. Hal tersebut dilakukan dengan menghitung kapasitas muat dari kapal berdasarkan masing-masing ukuran. Kapasitas muat kapal dihitung berdasarkan rumus berikut

Kapasitas muat $=\mathrm{V}$ x SF

$\mathrm{V}$ : volume palka $\left(\mathrm{m}^{3}\right)$

$\mathrm{SF}$ : stowage factor ikan dalam penempatan curah $\left(\mathrm{ton} / \mathrm{m}^{3}\right)$

Stowage factor merupakan faktor yang digunakan dalam menentukan besar palka. Stowage factor juga bergatung pada jenis dan ukuran ikan, metode penyimpanan ikan di dalam palka, suhu ikan ketika selama perjalanan dari fishing ground menuju fishing base lama peride palka, dan pebandingan es dan ikan yang dibutuhkan (Fyson 1985). SF dalam penyimpanan muatan hasil tangkapan yang digunakan sebesar 0,5 ton $/ \mathrm{m}^{3}$ yang artinya untuk menyimpan ikan sebesar 0,5 ton maka dibutuhkan ruang penyimpanan sebesar $1 \mathrm{~m}^{3}$ dalam bentuk penyimpanan curah. Analisis data dilakukan dengan metode deskriptif kualitatif. 


\section{HASIL DAN PEMBAHASAN}

\section{Kapal Penangkap Ikan di WPP 712}

Kapal penangkap ikan di Indonesia dibedakan menjadi 3 kategori berdasarkan gross tonnage (GT) yang dimiliki, yaitu kapal penangkap ikan skala besar, kapal penangkap ikan skala menengah, dan kapal penangkap ikan skala kecil (KKP 2015). Gross tonage merupakan tonase kotor yang dihitung berdasarkan volume ruang tertutup baik di atas maupun di bawah geladak kapal (Permenhub No. 8 tahun 2013). Selain GT juga dikenal tonase bersih (NT) (PP No. 51 tahun 2002). Berdasarkan perbandingan GT kapal tersebut untuk kapal penangkap ikan di WPP 712 didominasi oleh kapal penangkap ikan skala kecil dengan GT kapal $<30$ GT. Hal tersebut dimungkinkan karena WPP 712 sendiri termasuk dalam wilayah perairan dengan kedalaman yang dangkal yaitu $<200 \mathrm{~m}$. Sehingga kapal penangkap ikan di WPP 712 didominasi oleh kapal penangkap ikan skala kecil.

Menurut Permen-KP No. 36 tahun 2015 tentang Kriteria dan Pengelompokkan Skala Kecil, Skala Menengah, dan Skala Besar Dalam Pungutan Hasil Perikanan menyatakan bahwa kapal penangkap ikan skala kecil merupakan kapal penangkap ikan dan/atau kapal pendukung operasi penangkapan ikan diatas 30 (tiga puluh) GT sampai dengan 60 (enam puluh) GT, kapal penangkap ikan skala menengah merupakan kapal penangkap ikan atau kapal pendukung operasi penangkapan ikan diatas 60 (enam puluh) GT sampai dengan 200 (dua ratus) GT, dan kapal skala besar merupakan kapal penangkap ikan atau kapal pendukung operasi penangkapan ikan kapal diatas 200 (dua ratus) GT. Namun untuk kapal <30 GT juga dapat dikategorikan sebagai kapal penangkap ikan skala kecil. Adanya pembagian kategori ukuran kapal berdasarkan GT kapal tersebut digunakan untuk menentukan perizinan operasi penangkapan ikan yang dilakukan.

Pemerintah mengatur pembagian perizinan operasi penangkapan berdasarkan Undang-undang No. 23 tahun 2014 tentang pemerintahan daerah. Aturan tersebut menyatakan bahwa kapal penangkap ikan berukuran $<30$ GT menjadi pengawasan oleh pihak pemerintah daerah provinsi masing-masing dan untuk kapal penangkap ikan berukuran $>30 \mathrm{GT}$ akan menjadi kewenangan oleh pihak pemerintah pusat. Sehingga pada akhirnya masing-masing wilayah provinsi memiliki jumlah kapal penangkap ikan yang berbeda-beda satu dengan yang lainnya. Permen-KP No. 71 tahun 2016 tentang Jalur Penangkapan Ikan dan Penempatan Alat Penangkapan Ikan hanya menyebutkan bahwa salah satu ukuran kapal penangkap ikan yang dapat beroperasi di wilayah perairan termasuk kapal motor berukuran 5 GT hingga kapal motor berukuran diatas 30 GT, oleh karena itu hingga saat ini belum ada aturan khusus mengenai klasifikasi kapal berukuran $<30$ GT. Aturan yang tercantum dalam PermenKP No. 71 tahun 2016 juga menyatakan bahwa kapal penangkap ikan berukuran <30 GT dapat melakukan kegiatan penangkapan di wilayah perairan $>12$ mil dengan syarat kapal tersebut mampu melakukan operasi penangkapan di wilayah tersebut. Namun untuk kapal penangkap ikan berukuran $>30$ GT tidak diperkenankan melakukan kegiatan penangkapan di wilayah perairan $<12$ mil.

Berdasarkan hasil analisis yang telah dilakukan, kapal penangkap ikan di WPP 712 didominasi oleh kapal penangkap ikan berukuran <30 GT. Jumlah kapal penangkap ikan di WPP 712 mengalami perubahan fluktuatif sejak tahun 2009 hingga 2016. Jumlah kapal penangkap ikan tertinggi selama delapan tahun (2009-2016) terdapat pada tahun 2014 dengan total 98.828 unit dan jumlah kapal penangkap ikan paling sedikit terdapat pada tahun 2010 yaitu sebanyak 27.261 unit. Sebaran kapal penangkap ikan di WPP 712 sejak tahun 2009 hingga 2016 dapat dilihat pada Gambar 1. Jumlah tertinggi kapal penangkap ikan pada tahun 2014 didominasi oleh kapal penangkap ikan berukuran $<5$ GT dengan jumlah 53.636 unit kapal penangkap ikan, jumlah tersebut setara dengan 54\% dari total jumlah kapal penangkap ikan di WPP 712 pada tahun 2014. Kapal penangkap ikan yang mendominasi di tahun 2014 selanjutnya adalah kapal berukuran 5-10 GT dengan jumlah 30.414 unit dan kapal penangkap ikan berukuran 10-30 GT dengan jumlah 14.385 unit. Hal tersebut menunjukkan bahwa kegiatan operasi penangkapan ikan di WPP 712 pada tahun 2014 didominasi oleh operasi penangkapan ikan skala kecil. Sedangkan ukuran kapal >30 GT yang ada pada tahun 2014 berjumlah 393 unit kapal 
penangkap ikan, hal ini terdiri dari 82 unit berukuran 31-50 GT, 290 unit berukuran 51-100 GT, dan 21 unit kapal penangkap ikan berukuran 101-200 GT.

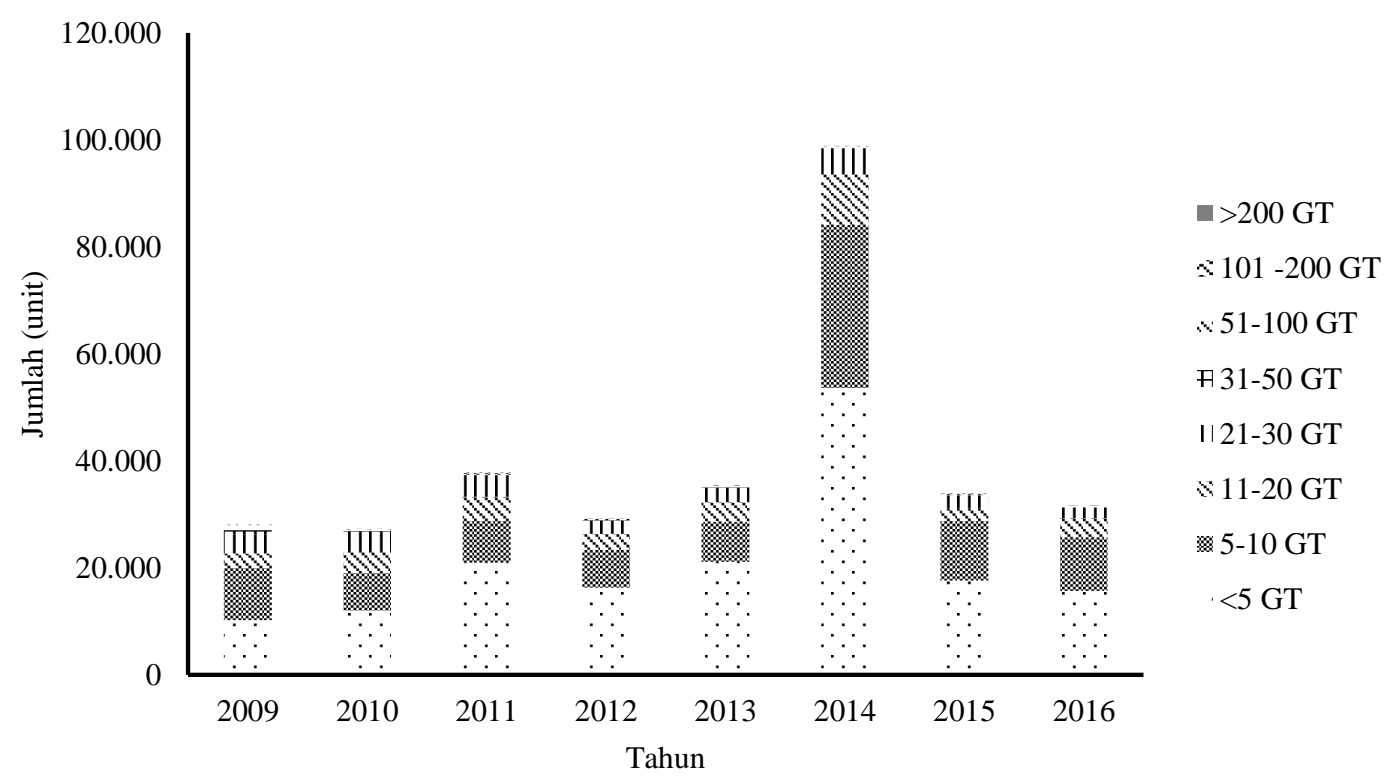

Gambar 1 Sebaran jumlah kapal penangkap ikan berbagai ukuran tahun 2009-2016 di WPP 712 (Sumber: Hasil pengolahan data penelitian, 2019)

Berdasarkan hasil pengolahan data statistik jumlah kapal penangkap ikan di WPP 712 mengalami penurunan pada tahun 2010, 2012, 2015, dan pada tahun 2016. Penurunan jumlah kapal penangkap ikan tertinggi terjadi pada tahun 2014 ke 2015, saat itu penurunan jumlah kapal penangkap ikan mencapai 64.957 unit kapal. Penurunan jumlah kapal yang terjadi di tahun 2015 didominasi oleh kapal berukuran <5 GT dan 5-10 GT. Pada tahun 2012 juga terjadi penurunan jumlah kapal penangkap ikan yang didominasi oleh kapal berukuran <30 GT. Total penurunan jumlah kapal penangkap ikan yang terjadi di tahun 2012 berjumlah 8.540 unit kapal. Penambahan jumlah kapal penangkap ikan terjadi pada tahun 2011, 2013, dan 2014. Tahun 2014 jumlah kapal penangkap ikan mengalami penambahan tertinggi selama delapan tahun tersebut yaitu dengan total penambahan berjumlah 63.469 unit kapal. Penambahan jumlah kapal penangkap ikan di tahun 2014 didominasi oleh kapal berukuran <5 GT dan 5-10 GT. Penambahan jumlah kapal di tahun 2011 dan 2013 juga terjadi pada kapal berukuran <30 GT. Menurut Hidayat (2009) menyatakan bahwa adanya penambahan jumlah kapal penangkap ikan tidak selalu disertai dengan meningkatnya tingkat produksi tangkapan ikan yang dilakukan. Hal tersebut mengindikasikan bahwa pemanfaatan sumber daya ikan di suatu wilayah sudah mengalami kapasitas berlebih input produksi (excess capacity). Kapal penangkap ikan berukuran kecil memiliki keterbatasan modal dan teknologi sehingga jangkauan penangkapan yang terbatas dan terkonsentrasi pada wilayah dekat pantai. Tingginya jumlah kapal penangkap ikan berukuran $<30$ GT pada tahun 2014 terutama kapal berukuran <10 GT mendukung pernyataan Triarso (2012) yang menyatakan bahwa perikanan di Pantai Utara Jawa perikanan tangkap yang terjadi beroperasi di perairan pantai sehingga wilayah tersebut didominasi oleh perikanan tangkap skala kecil.

\section{Wilayah Perairan dan Potensi Sumber Daya Ikan di WPP 712}

Total luas wilayah perairan WPP 712 sebesar 414.461.865.299,71 $\mathrm{m}^{2}$ luas wilayah perairan ini dihitung berdasarkan titik batas wilayah WPP 712 yang tercantum dalam Permen-KP No. 18 tahun 2014 tentang Wilayah Pengelolaan Perikanan Negara Republik Indonesia. Luas wilayah perairan tersebut kemudian dibagi untuk masing-masing provinsi di WPP 712 sebagai wilayah daerah. WPP 712 terdiri dari delapan wilayah administrasi yaitu Provinsi DKI Jakarta, Jawa Barat, Jawa Tengah, Jawa 
Timur, Kalimantan Tengah, Lampung, Banten, dan Kalimantan Selatan dengan luasan wilayah perairan yang berbeda-beda antar provinsi. Luasan perairan provinsi dihitung sejauh 12 mil dari garis pantai. Luasan perairan masing-masing provinsi di WPP 712 tersaji pada Tabel 2.

Tabel 2 Luas wilayah perairan masing-masing provinsi di WPP 712

\begin{tabular}{llc}
\hline \multicolumn{1}{c}{ Provinsi } & \multicolumn{1}{c}{ Luas area $\left(\mathrm{m}^{2}\right)$} & Zona tangkap \\
\hline Banten & $1.843 .183 .397,57$ & \\
DKI Jakarta & $5.840 .893 .269,12$ & \\
Jawa Barat & $8.107 .989 .057,66$ & \\
Jawa Tengah & $13.813 .579 .951,30$ & Daerah \\
Jawa Timur & 39.153 .389 .868 & \\
Lampung & $5.789 .985 .063,38$ & \\
Kalimantan Tengah & $12.606 .574 .431,30$ & \\
Kalimantan Selatan & $4.980 .804 .242,38$ & Pusat \\
\hline Area non provinsi $(>12 \mathrm{mil})$ & 322.325 .466 .019 & \\
\hline
\end{tabular}

(Sumber : Hasil pengolahan data penelitian, 2019)

Perbandingan luasan wilayah perairan di WPP 712 dapat digunakan untuk membagi zona wilayah kewenangan antara pemerintah pusat dan daerah. Wilayah perairan provinsi menjadi kewenangan pemerintah daerah dalam hal pengelolaan dan kebijakan yang dilakukan. Berdasarkan Undang-undang No.23 tahun 2014 tentang pemerintahan daerah menyatakan bahwa pemerintahan daerah memiliki kewenangan untuk mengelola sumber daya alam di laut, melakukan pengaturan administratif, pengaturan tata ruang, ikut serta dalam memelihara keamanan di laut, dan ikut serta dalam mempertahankan kedaulatan negara paling jauh 12 (dua belas) mil laut diukur dari garis pantai ke arah laut lepas atau ke arah perairan kepulauan. Pembagian wilayah perairan di WPP 712 dapat dilihat pada Gambar 2.

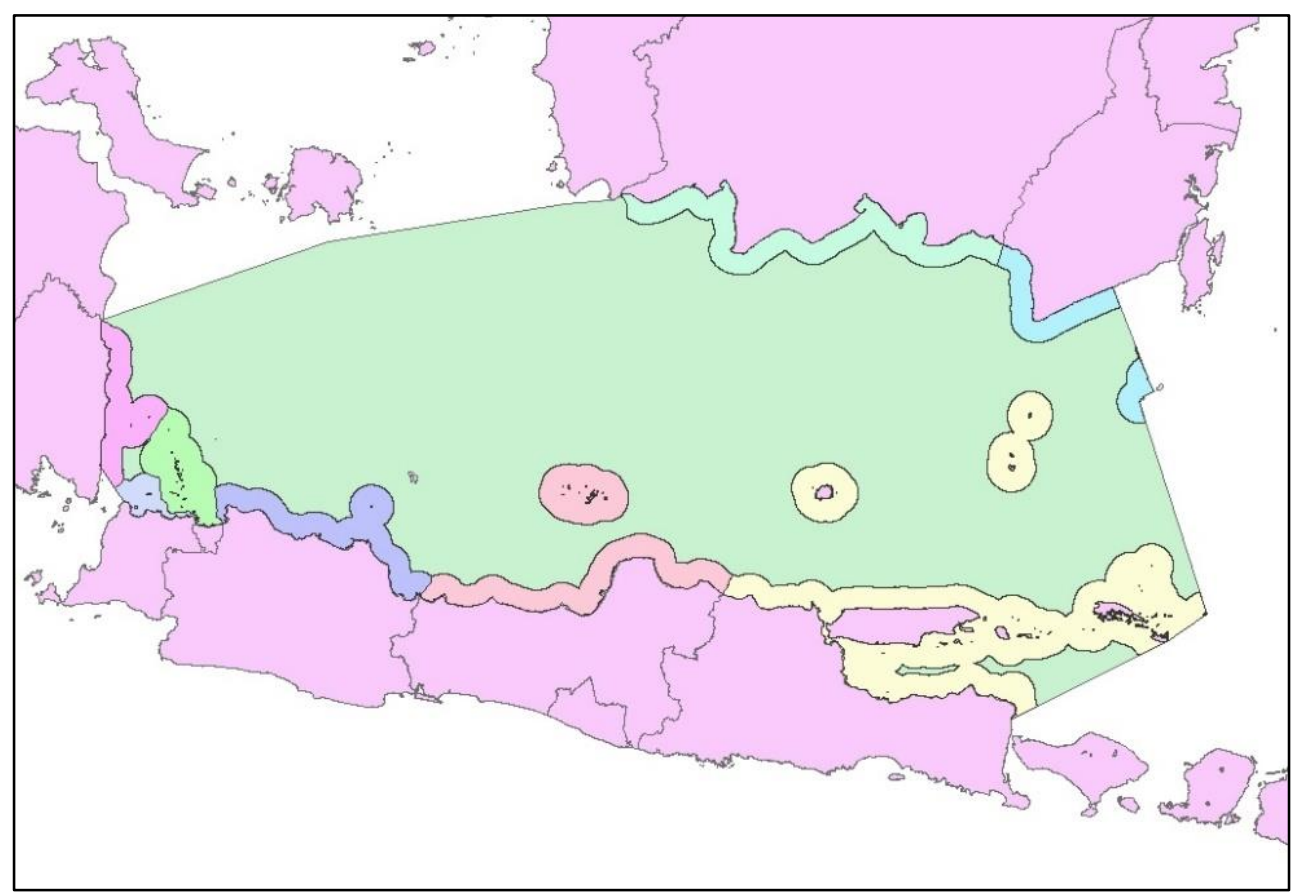

Gambar 2 Wilayah perairan masing-masing provinsi di WPP 712

(Sumber: Hasil analisis data penelitian, 2019)

Adanya pengaturan mengenai zona tangkap pada akhirnya menimbulkan beberapa permasalahan seperti konflik nelayan antar daerah dan permasalahan terkait ukuran kapal yang 
diizinkan untuk menangkap di zona tertentu. Kapal berukuran <30 GT saat ini menjadi kewenangan pemerintah daerah dalam hal perizinan dengan wilayah tangkap sejauh 12 mil dari garis pantai. Kapal berukuran $>30$ GT menjadi kewenangan pemerintah pusat dalam hal perizinan dengan wilayah tangkap hingga 200 mil dari garis pantai. Permasalahan terkait ukuran kapal yang di mark down agar kapal mendapatkan izin dari pemerintah daerah sering ditemukan sehingga perlu adanya pembatasan jumlah kapal penangkap ikan di masing-masing wilayah baik daerah dan pusat.

Potensi sumber daya ikan di WPP 712 pada mulanya dikaji setiap 5 tahun sekali oleh Kementerian Kelautan dan Perikanan melalui Komisi Nasional Pengkajian Sumber Daya Ikan (Kajiskan) namun sejak tahun 2016, estimasi potensi, jumlah tangkapan yang diperbolehkan, dan tingkat pemanfaatan sumber daya ikan dikaji setiap satu tahun sekali. Sehingga estimasi potensi yang digunakan sebagai acuan dalam kegiatan upaya penangkapan ikan pada tahun 2016 dan 2017 berbeda. Potensi sumber daya ikan yang digunakan selama delapan tahun terakhir tersaji pada Tabel 3.

Tabel 3 Potensi sumber daya ikan di WPP 712

\begin{tabular}{lrrr}
\hline \multirow{1}{*}{ Kategori SDI } & \multicolumn{3}{c}{ Potensi sumber daya ikan (ton) } \\
\cline { 2 - 4 } & $\mathbf{2 0 1 1}$ & \multicolumn{1}{c}{$\mathbf{2 0 1 6}$} & \multicolumn{1}{c}{$\mathbf{2 0 1 7}$} \\
\hline Ikan Pelagis Kecil & 380.000 & 303.886 & 364.663 \\
Ikan Pelagis Besar & 55.000 & 104.017 & 72.812 \\
Ikan Demersal & 375.200 & 320.432 & 657.525 \\
Ikan Karang & 9.500 & 59.146 & 29.951 \\
Udang Penaeid & 11.400 & 58.390 & 57.965 \\
Lobster & 500 & 952 & 989 \\
Kepiting & - & 10.077 & 7.664 \\
Rajungan & - & 22.637 & 23.508 \\
Cumi-cumi & 5.000 & 102.142 & 126.554 \\
Total & 836.600 & 981.679 & 1.341 .631 \\
\hline
\end{tabular}

Sumber : Kepmen-KP No. 45 tahun 2011

Kepmen-KP No. 47 tahun 2016

Kepmen-KP No. 50 tahun 2017

Jumlah potensi sumber daya ikan sejak tahun 2011 hingga 2016 secara garis besar mengalami kenaikan yang cukup signifikan namun dalam beberapa kategori terjadi penurunan nilai potensi sumber daya ikan seperti pada potensi ikan demersal. Menurut Ma'mun et al. (2018) sumber daya ikan demersal di tahun 2011-2015 terjadi kecenderungan penurunan potensi lestari ikan dan hal tersebut menunjukkan status sumberdaya ikan demersal telah terjadi overfishing dan degradasi sumberdaya. Upaya pemerintah yang dilakukan pada tahun 2015 yaitu dengan pelarangan penggunaan salah satu alat penangkapan ikan menyebabkan tekanan dalam upaya penangkapan ikan menurun sehingga potensi ikan demersal jika dibandingkan dengan potensi pada tahun 2017 mengalami kenaikan. Berbeda halnya dengan kategori ikan pelagis kecil yang sempat mengalami penurunan jumlah potensi di tahun 2016 namun kemudian potensi ikan tersebut naik kembali di tahun 2017. Kelompok ikan pelagis kecil yang didominasi ikan planktivora merupakan kategori ikan dengan nilai kerentanan yang cukup tinggi sehingga perlu adanya pengawasan terhadap kegiatan penangkapan pada kelompok ikan tersebut. Mengacu pada pernyataan Sadhotomo B dan Atmaja SB (2012) yang menyatakan bahwa perlu adanya upaya pembatasan penangkapan baik dari sisi pengurangan jumlah kapal maupun pengendalian terhadap kapasitas dan taktitk penangkapan ikan di Perairan Laut Jawa. Maka hal tersebut menunjukkan pentingnya pengendalian terhadap upaya penangkapan ikan yang dilakukan.

Total jumlah tangkapan yang diperbolehkan dalam kegiatan penangkapan ikan sebesar 80\% dari potensi yang ada. Nilai jumlah tangkapan yang diperbolehkan menunjukkan total sumber daya ikan yang dapat digunakan dalam kegiatan penangkapan ikan. Jumlah tangkapan yang diperbolehkan ini 
yang menjadi batasan dalam menentukan input upaya penangkapan. Salah satu input dalam kegiatan perikanan tangkap adalah adalah kapal penangkap ikan. Menurut Suman et al. (2015) menyatakan bahwa untuk mewujudkan pengelolaan dan pemanfaatan sumber daya ikan di Indonesia, maka harus dilakukan perbaikan kebijakan pengelolaan dengan acuan angka potensi dan tingkat pemanfaatan sumber daya ikan yang berlaku. Salah satu upaya yang mendesak dilakukan adalah dengan restrukturisasi armada di WPP dengan titik acuan berupa upaya yang optimal.

Input dalam upaya penangkapan ikan perlu dibatasi untuk mencegah terjadinya penangkapan berlebih, hal ini berarti jumlah kapal penangkap ikan yang beroperasi juga perlu dibatasi. Pembatasan jumlah kapal penangkap ikan dihitung berdasarkan kapasitas muat dan jumlah tangkapan yang diperbolehkan pada zona tangkap daerah dan pusat. Perbandingan nilai tangkap yang diperbolehkan berdasarkan luasan wilayah perairan dan kapasitas tangkap pada masing-masing zona tangkap tersaji pada Tabel 4.

Tabel 4 Luas wilayah dan jumlah tangkapan yang diperbolehkan di WPP 712 berdasarkan zona tangkap

\begin{tabular}{lrrr}
\hline & Wilayah perairan $\left(\mathrm{m}^{2}\right)$ & Volume palka $\left(\mathrm{m}^{3}\right)$ & \multicolumn{1}{c}{ JTB (ton) } \\
\hline Daerah & $92.136 .399 .280,71$ & $411.993,33$ & $600.650,50$ \\
Pusat & 322.325 .466 .019 & $47.333,33$ & $472.654,30$ \\
\hline Total & $414.461 .865 .299,71$ & $459.326,67$ & $1.073 .304,80$ \\
\hline
\end{tabular}

(Sumber : Hasil pengolahan dan analisis data penelitian, 2019)

\section{Jumlah Kapal Penangkap Ikan Berdasarkan Zona Tangkap}

Perbedaan jumlah tangkapan yang diperbolehkan antara zona tangkap daerah dan pusat akan menimbulkan perbedaan jumlah kapal optimal yang dapat beroperasi di kedua zona tersebut. Berdasarkan perbandingan jumlah kapal tertinggi dari masing-masing ukuran selama delapan tahun (2009-2016) maka diperoleh perbandingan jumlah kapal yang dapat beroperasi disesuaikan dengan potensi dan jumlah tangkapan yang diperbolehkan. Adanya pembatasan jumlah tangkapan yang diperbolehkan dimaksudkan untuk menjaga kesediaan sumber daya ikan agar tetap lestari. Jumlah kapal optimal berdasarkan perbandingan jumlah tangkapan yang diperbolehkan dengan kapasitas muat kapal masing-masing ukuran kapal tersaji pada Tabel 5.

Tabel 5 Jumlah kapal optimal berdasarkan kapasitas muat dan jumlah tangkapan yang diperbolehkan

\begin{tabular}{lccccc}
\hline \multirow{2}{*}{ Ukuran kapal } & $\begin{array}{c}\text { Kapasitas } \\
\text { muat ikan }\end{array}$ & \multicolumn{2}{c}{ Total Estimasi GT Kapal } & $\begin{array}{c}\text { Perbandingan } \\
\text { jumlah kapal* }\end{array}$ & $\begin{array}{c}\text { Estimasi } \\
\text { Jumlah } \\
\text { Kapal }\end{array}$ \\
\cline { 3 - 4 } & & Daerah & Pusat & & \\
\hline$<5$ GT & 3,33 & $180.195,15$ & & 0,53 & 19.831 \\
$5-10$ GT & 5 & $120.130,10$ & & 0,29 & 7.146 \\
$11-20$ GT & 10,33 & $58.127,47$ & & 0,11 & 2.561 \\
$21-30$ GT & 17 & $35.332,38$ & & 0,08 & 1.185 \\
$31-50$ GT & 27 & & $17.505,71$ & 0,31 & 4.496 \\
$51-100$ GT & 50,33 & & $9.390,48$ & 0,64 & 8.395 \\
$101-200$ GT & 100,33 & & $4.710,84$ & 0,05 & 630 \\
\hline & & & \multicolumn{3}{c}{ Total } \\
\hline
\end{tabular}

(Sumber: Hasil pengolahan data penelitian, 2019)

Berdasarkan hasil pada Tabel 5 menunjukkan bahwa jumlah total kapal penangkap ikan yang dapat beroperasi di WPP 712 sejumlah 44.243 unit kapal penangkap ikan, dengan pembagian 
berdasarkan zona tangkap sebesar 30.723 unit kapal berukuran <5 GT hingga 21-30 GT dan 13.521 unit kapal penangkap ikan berukuran 31-50 GT hingga kapal berukuran $>200$ GT. Jumlah total kapal tersebut diperoleh berdasarkan perbandingan nilai estimasi tangkapan dengan kapasitas muat ikan pada masing-masing ukuran kapal. Jumlah total kapal penangkap ikan diatas dihitung berdasarkan posisi penyimpanan ikan yang dilakukan dalam bentuk penyimpanan curah, maka jumlah kapal penangkap ikan akan berubah apabila kapasitas muat ikan dihitung dalam kondisi penyimpanan ikan dilakukan dalam bentuk boxes atau shelves.

Total kapal yang dapat beroperasi di WPP 712 pada Tabel 5 merupakan total kapal yang dapat beroperasi berdasarkan jumlah tangkapan yang diperbolehkan yang berlaku saat ini. Hasil tersebut menunjukan bahwa input dalam upaya penangkapan dapat dihitung berdasarkan kapasitas muat ikan yang mampu disimpan oleh kapal dari berbagai ukuran, sehingga perlu adanya pengendalian terhadap jumlah kapal penangkap ikan yang beroperasi di WPP 712 agar kondisi sumber daya ikan dapat terjaga. Menurut Metzner (2005) menyatakan bahwa pengendalian inputproduksi dalam jangka pendek seperti pembatasan jumlah kapal dapat mengurangi hasil tangkapan aktual namun dalam jangka panjang dapat memberikan pengaruh berupa peningkatan kapasitas penangkapan. Oleh karena itu, salah satu upaya jangka pendek untuk mengatasi tingginya input dalam upaya penangkapan yang terjadi adalah dengan mengurangi jumlah input upaya penangkapan dan membatasi akses kapal baru serta meningkatkan pengawasan terhadap masuknya kapal-kapal penangkap ikan dari daerah lain tanpa izin. Penerapan solusi jangka pendek tersebut diharapkan dapat memberikan kesempatan bagi sumber daya ikan agar dapat pulih dan meningkatkan pertumbuhan populasi ikan. Sehingga pengaruh jangka panjang berupa peningkatan kapasitas penangkapan dapat terjadi dengan kondisi sumber daya ikan yang meningkat di kemudian hari.

\section{KESIMPULAN}

Distribusi kapal penangkap ikan di WPP 712 tahun 2009-2016 mengalami perubahan fluktuatif dengan jumlah total kapal penangkap ikan tertinggi pada tahun 2014 berjumlah 98.828 unit kapal penangkap ikan yang didominasi oleh kapal berukuran $<30 \mathrm{GT}$. Jumlah kapal yang dapat beroperasi di zona tangkap daerah sesuai dengan potensi dan JTB yang berlaku saat ini adalah 44.243 unit kapal penangkap ikan, dengan pembagian berdasarkan zona tangkap sebesar 30.723 unit kapal berukuran $<5$ GT hingga 21-30 GT dan 13.521 unit kapal penangkap ikan berukuran 31-50 GT hingga kapal berukuran $>200 \mathrm{GT}$.

\section{SARAN}

Alokasi jumlah kapal penangkap ikan di WPP 712 dapat ditambah namun hal tersebut sebaiknya dilakukan terhadap kapal berukuran $>30$ GT dan perlu ada kajian lebih lanjut mengenai kapasitas muat kapal masing-masing ukuran sehingga dapat dijadikan acuan dalam menentukan kapasitas hasil tangkapan dalam operasi penangkapan ikan.

\section{UCAPAN TERIMA KASIH}

Ucapan terima kasih disampaikan kepada Lembaga Pengelola Dana Pendidikan (LPDP) dan Kementerian Kelautan dan Perikanan yang telah membantu dan mendukung kegiatan penelitian ini.

\section{DAFTAR PUSTAKA}

[KKP]. Kementerian Kelautan dan Perikanan. 2010. Keputusan Menteri Kelautan dan Perikanan Republik Indonesia Nomor 06 tahun 2010 tentang Alat Penangkapan Ikan di Wilayah Pengelolaan Perikanan Negara Republik Indonesia. 
[KKP]. Kementerian Kelautan dan Perikanan. 2012. Peraturan Menteri Kelautan dan Perikanan Republik Indonesia No. 30 Tahun 2012 Tentang Usaha Perikanan Tangkap di Wilayah Pengelolaan Perikanan Negara Republik Indonesia.

[KKP]. Kementerian Kelautan dan Perikanan. 2014. Peraturan Menteri Kelautan dan Perikanan Republik Indonesia No. 18 Tahun 2014 Tentang Wilayah Pengelolaan Perikanan Negara Republik Indonesia.

[KKP]. Kementerian Kelautan dan Perikanan. 2015. Peraturan Menteri Kelautan dan Perikanan Republik Indonesia No. 36 Tahun 2015 Tentang Kriteria Dan Pengelompokan Skala Kecil, Skala Menengah, Dan Skala Besar Dalam Pungutan Hasil Perikanan.

[KKP]. Kementerian Kelautan dan Perikanan. 2016. Peraturan Menteri Kelautan dan Perikanan Republik Indonesia No. 71 Tahun 2016 Tentang Jalur Penangkapan Ikan dan Penempatan Alat Penangkapan Ikan.

[KKP]. Kementerian Kelautan dan Perikanan. 2017. Keputusan Menteri Kelautan dan Perikanan Republik Indonesia No. 50 Tahun 2017 Tentang Estimasi Potensi, Jumlah Tangkapan Yang Diperbolehkan, Dan Tingkat Pemanfaatan Sumber Daya Ikan Di Wilayah Pengelolaan Perikanan Negara Republik Indonesia.

Fyson J. 1985. Design of Small Fishing Vessel. FAO, Rome: Italy

Hidayat AS. 2009. Analisis Kapasitas Unit Penangkapan Ikan Skala Kecil (Kasus Perikanan Pelagis Di Kabupaten Bangka). [Tesis]. Institut Pertanian Bogor. Bogor.

Kementerian Kelautan dan Perikanan. 2011. Status WPP 712 Berdasarkan Indikator EAFM [Internet]. [diakses pada 2 Agustus 2018]. Tersedia pada http://www.eafm-indonesia.net/data/status/712.

Kementerian Kelautan dan Perikanan. 2012. Jumlah Kapal Menurut Jenis Kapal dan Provinsi [Internet]. [diakses pada 15 Agustus 2018]. Tersedia pada http://statistik.kkp.go.id/sidatikdev/index.php?s=3\#.

Ma'mun A, Priatna A, Suwarso, Natsir M. 2018. Potensi dan Distribusi Spasial Ikan Demersal di Laut Jawa (WPP NRI-712) dengan Menggunakan Teknologi Hidroakustik. J ITKT. 10(2): 489-500.

Metzner R. 2005. Fising Aspirations and Fishing Capacity. Two Key Management Issues. Paper presented in Conference on the Governance of High Seas Fisheries and The UN Fish Agreement: Moving from Words to Action, ST John's, New Foundland and Labrador., May 1 to 5, 2005. International Journal Marine and Coastal Law. 20(3-4):469-478.

PM 8 Tahun 2013. Tentang Pengukuran Kapal Kementerian Perhubungan Direktorat Jenderal Perhubungan Laut

Sadhotomo B, Atmaja SB. 2012. Sintesa kajian Stok Ikan Pelagis Kecil Di Laut Jawa. J PPI. 18(4): 221232.

Suman A, Irianto HE, Satria F, Amri K. 2016. Potensi dan Tingkat Pemanfaatan Sumber Daya Ikan di Wilayah Pengelolaan Perikanan Negara Republik Indonesia (WPP NRI) Tahun 2015 serta Opsi Pengelolaannya. J KPI. 8(2):97-110.

Triarso I. 2012. Potensi dan Peluang Pengembangan Usaha Perikanan Tangkap di Pantura Jawa Tengah. J Saintek Perikanan. 8(1):65-73.

Undang-undang No. 23 tahun 2014 tentang pemerintah daerah. 